\title{
Preliminary Study towards Enhanced Crude Oil Biodegradation Reveals Congeneric Total Peroxidases with Striking Distinctions
}

\author{
Folasade M. Olajuyigbe*, Kevin I. Ehiosun, Kikelomo F. Jaiyesimi \\ Enzyme Biotechnology Unit, Department of Biochemistry, Federal University of Technology, Akure, Nigeria \\ Email: folajuyi@futa.edu.ng
}

Received 18 July 2015; accepted 4 September 2015; published 7 September 2015

Copyright (C) 2015 by authors and Scientific Research Publishing Inc.

This work is licensed under the Creative Commons Attribution International License (CC BY). http://creativecommons.org/licenses/by/4.0/

c) (i) Open Access

\begin{abstract}
Peroxidases (POXs) are the key extracellular enzymes produced by crude oil degrading microbes. Knowledge of optimum conditions for POXs activity is crucial for providing effective environment for bioremediation. In this study, physicochemical properties of POXs produced by Actinomyces israelii and Actinomyces viscosus during growth on crude oil were studied. The POXs exhibited similarities in activity and stability with striking differences in response to two divalent metal ions. The POXs from both species had optimum $\mathrm{pH}$ of 7.0 and were very stable over a narrow $\mathrm{pH}$ range (6.0 - 8.0). The POXs demonstrated similar thermostability exhibiting relative residual activity of $62 \%$ at $50^{\circ} \mathrm{C}$ after $30 \mathrm{~min}$ incubation and $45 \%$ residual activity at the same temperature after 60 min despite the fact that POXs from $A$. viscosus and $A$. israelii had optimum temperatures of $50^{\circ} \mathrm{C}$ and $40^{\circ} \mathrm{C}$, respectively. The POXs from $A$. viscosus and $A$. israelii were greatly activated by $\mathrm{Fe}^{2+}$ at 5.0 and $10.0 \mathrm{mM}$. The enzymes were both strongly inhibited by $\mathrm{Cu}^{2+}, \mathrm{Mg}^{2+}$ and $\mathrm{Hg}^{2+}$. Surprisingly, these congeneric POXs demonstrated striking differences in their response to $\mathrm{Ca}^{2+}$ and $\mathrm{Mn}^{2+}$. $\mathbf{P O X}$ from $A$. viscosus was activated by $\mathrm{Ca}^{2+}$ and $\mathrm{Mn}^{2+}$ exhibiting relative activity of $136 \%$ and $106 \%$ at 5 $\mathrm{mM}$, respectively. In contrast, $\mathrm{POX}$ from $A$. israelii was strongly inhibited by $\mathrm{Ca}^{2+}$ and $\mathrm{Mn}^{2+}$ exhibiting $62.5 \%$ relative activity in the presence of $5 \mathrm{mM}$ of each metal ion. Increasing the concentration of $\mathrm{Ca}^{2+}$ and $\mathrm{Mn}^{2+}$ led to further activation of POX from $A$. viscosus and inhibition of POX from $A$. israelii. Results provide deeper insights into functional properties of studied POXs from closely related microbes. The physicochemical properties are very similar; however, notable differences provide a strong basis for structural characterization of these congeneric enzymes.
\end{abstract}

\section{Keywords}

Actinomyces israelii, Actinomyces viscosus, Bioremediation, Congeneric Enzymes, Crude Oil, Peroxidases

\footnotetext{
${ }^{*}$ Corresponding author.
}

How to cite this paper: Olajuyigbe, F.M., Ehiosun, K.I. and Jaiyesimi, K.F. (2015) Preliminary Study towards Enhanced Crude Oil Biodegradation Reveals Congeneric Total Peroxidases with Striking Distinctions. Advances in Enzyme Research, 3, 66-74. 


\section{Introduction}

Crude oil spills have caused destruction of farmlands, contamination of water bodies and loss of biodiversity [1] [2]. Crude oil is a natural, heterogeneous mixture of hydrocarbons, consisting mainly of alkanes with different chain lengths and branch points, cycloalkanes, mono-aromatic and polycyclic aromatic hydrocarbons. Some compounds contain nitrogen, sulfur and oxygen with trace amounts of phosphorus while presence of heavy metals such as nickel and vanadium has also been reported [3] [4]. Many polycyclic aromatic hydrocarbons (PAHs) in crude oil are highly toxic, mutagenic and carcinogenic to microorganisms and higher systems including humans [5].

Among the different remediation techniques, bioremediation is the most advantageous due to its cost effectiveness and environmental friendliness [6] [7]. This has led to screening for various microorganisms with high crude oil degrading efficiency. Actinobacteria have been reported as useful microbes in the bioremediation of soils contaminated with crude oil and derivatives [8]-[10]. A wide variety of microbes initiate biodegradation of polyaromatic and aliphatic hydrocarbons by co-metabolism using extracellular and intracellular enzymes of which peroxidases play a crucial role [11] [12]. Enzymes involved in the degradation of PAHs are oxygenase, dehydrogenase and lignolytic enzymes comprising peroxidases and laccases [13]. Peroxidases (POXs) have been considered useful in the degradation of organic pollutants, especially, poly aromatic hydrocarbons [14][16]. Peroxidases are redox enzymes which are found in all forms of life where they play diverse roles. It is quite surprising that peroxidases isolated from fungi and plants have been extensively studied while actinobacterial peroxidases have been unexplored despite their diverse metabolic capabilities which represent large resource for biocatalysis [17].

It is very important to note that the microorganisms used for bioremediation secrete extracellular enzymes which initiate the degradation of the crude oil hydrocarbons. Knowledge of the optimum conditions for the activity of secreted enzymes is envisaged to provide effective environment for bioremediation by the crude oil degrading microbes. Since peroxidases are the key extracellular enzymes involved in crude oil biodegradation, it is highly pertinent to determine physicochemical properties of the peroxidases produced by crude oil degrading microbes.

In this study, whole cells of Actinomyces israelii and Actinomyces viscosus were used to degrade crude oil and the activity of total extracellular peroxidases (POXs) produced by the organisms during biodegradation was determined. Physicochemical properties of POXs from the two species of the same genus, Actinomyces, were investigated with the aim of determining the optimal conditions for the activity of the enzymes for effective use of the actinobacteria in crude oil degradation. Comparative analysis of the exhibited physicochemical properties of the congeneric POXs was carried out.

\section{Materials and Methods}

\subsection{Materials}

Media components were products of Sigma-Aldrich (St. Louis, MO, USA). All other chemicals used were of analytical grade and obtained from Sigma-Aldrich.

\subsection{Microorganism, Culture Preparation and Peroxidase (POX) Production}

The microorganisms used for this study were isolated from soil samples of crude oil spill site in Ogoniland, Niger Delta region of Nigeria. The isolation and identification of isolates were done by the Biotechnology Unit of Federal Institute of Industrial Research, Lagos based on methods described in Bergey's Manual of Systematic Bacteriology [18]. The isolates used for this study were identified as Actinomyces viscosus and Actinomyces israelii. They were maintained on nutrient agar slants and stored at $4{ }^{\circ} \mathrm{C}$. The seed inoculum was prepared by growing a loopful of slant culture in nutrient broth containing peptone $(5 \mathrm{~g} / \mathrm{L}), \mathrm{NaCl}(5 \mathrm{~g} / \mathrm{L})$, beef extract $(1.5 \mathrm{~g} / \mathrm{L})$ and yeast extract $(1.5 \mathrm{~g} / \mathrm{L})$ at $\mathrm{pH}$ 7.4. The seed culture was incubated at $30^{\circ} \mathrm{C}$ for $24 \mathrm{~h}$ at $180 \mathrm{rpm}$ in a shaking incubator (Stuart, UK) and used as inoculum (5\% v/v) for crude oil based medium (COBM). The COBM contained $1 \%$ crude oil as sole carbon source, $\mathrm{NH}_{4} \mathrm{NO}_{3}(2.0 \mathrm{~g} / \mathrm{L}), \mathrm{KH}_{2} \mathrm{PO}_{4}(0.2 \mathrm{~g} / \mathrm{L}), \mathrm{KH}_{2} \mathrm{PO}_{4} \cdot 12 \mathrm{H}_{2} \mathrm{O}(0.2 \mathrm{~g} / \mathrm{L}), \mathrm{NaCl}(0.8$ $\mathrm{g} / \mathrm{L}), \mathrm{KCl}(0.8 \mathrm{~g} / \mathrm{L}), \mathrm{CaCl}_{2} \cdot 2 \mathrm{H}_{2} \mathrm{O}(0.1 \mathrm{~g} / \mathrm{L}), \mathrm{MgSO}_{4}(0.2 \mathrm{~g} / \mathrm{L})$ and $\mathrm{FeSO}_{4} \cdot 7 \mathrm{H}_{2} \mathrm{O}(0.002 \mathrm{~g} / \mathrm{L})$, pH 7.0. Cultures grown on COBM were incubated at $30^{\circ} \mathrm{C}$ for $144 \mathrm{~h}$ at $180 \mathrm{rpm}$. At the end of the cultivation period, the broths were centrifuged at $10,000 \mathrm{rpm}$ for $20 \mathrm{~min}$ at $4^{\circ} \mathrm{C}$. The clear supernatants were recovered and assayed for total POX activity. The total peroxidase activities produced from Actinomyces viscosus and Actinomyces israelii were 1.03 
U/L and 1.54 U/L, respectively (unpublished data). The crude enzyme solution was subjected to further studies.

\subsection{Assay of Total Peroxidase (POX) Activity}

Total POX activity was determined according to the method of Hunter et al. [19] with slight modifications. POX activity was determined via oxidation of $0.24 \mathrm{mM}$ 2,2'azino-di-[3-ethyl benzothiazoline-6-sulphonic acid] (ABTS) buffered with $50 \mathrm{mM}$ sodium acetate buffer $\mathrm{pH} 5$ in the presence of $5 \mathrm{mM} \mathrm{H}_{2} \mathrm{O}_{2}$ at $414 \mathrm{~nm}$ for $5 \mathrm{~min}$ in a UV/Visible spectrophotometer. The reaction mixture ( $3 \mathrm{~mL}$ ) was made up of $1 \mathrm{~mL}$ ABTS solution, $1 \mathrm{~mL}$ enzyme solution and $1 \mathrm{~mL} \mathrm{H}_{2} \mathrm{O}_{2}$ solution. Controls were set up as the reaction mixture without crude enzyme; 50 $\mathrm{mM}$ sodium acetate buffer pH $5(1 \mathrm{~mL})$ replaced the enzyme solution. One unit (U) of peroxidase activity was defined as the amount of enzyme oxidizing $1 \mu \mathrm{mol}$ ABTS per minute at $\mathrm{pH} 5.0$ and $30^{\circ} \mathrm{C}$ with a molar extinction coefficient for the ABTS radical cation of $31,100 \mathrm{M}^{-1} \cdot \mathrm{cm}^{-1}$ at $414 \mathrm{~nm}$.

\subsection{Investigation of Physicochemical Properties of Total POXs from A. viscosus and A. israelii}

\subsubsection{Effect of pH on Total POX Activity and Stability}

The effect of $\mathrm{pH}$ on activity of the crude total POX was determined over a $\mathrm{pH}$ range of 5.0 - 9.0. The $\mathrm{pH}$ was adjusted using $50 \mathrm{mM}$ of the following buffer solutions: sodium acetate (pH 5.0 - 5.5), sodium citrate (6.0 - 6.5), Tris-HCl (pH 7.0 to 8.5) and glycine- $\mathrm{NaOH}(\mathrm{pH} 9.0)$, respectively. POX activity was determined using the standard assay method earlier described. $\mathrm{pH}$ stability of total POX was determined by incubating the crude extract with relevant buffer solution for $24 \mathrm{~h}$ before assay of the residual activity which was done according to the standard assay procedure.

\subsubsection{Effect of Temperature on Total POX Activity and Stability}

The activity of total POX was determined in the reaction mixture at different temperatures ranging from $30^{\circ} \mathrm{C}$ to $70^{\circ} \mathrm{C}$ according to the standard assay procedure earlier described. Stability of total POX at different temperatures was carried out by prior incubation of the enzyme solution at temperatures ranging from $40^{\circ} \mathrm{C}$ to $70^{\circ} \mathrm{C}$ over a period of 30 to 180 min before determination of residual activity following the standard assay procedure.

\subsubsection{Effect of EDTA and Divalent Metal Ions on Total POX Activity}

Effect of 5 and $10 \mathrm{mM}$ of metal chelating agent, ethylene diamine tetra acetic acid (EDTA) on POX activity was determined. Also, effects of divalent metal ions $\left(\mathrm{Ca}^{2+}, \mathrm{Cu}^{2+}, \mathrm{Fe}^{2+}, \mathrm{Mg}^{2+}, \mathrm{Mn}^{2+}, \mathrm{Hg}^{2+}\right)$ on POX activity were evaluated at 5 and $10 \mathrm{mM}$. Each metallic chloride was added to the reaction mixture at the optimum temperature and $\mathrm{pH}$ determined for the enzyme and POX activity was determined in comparison with controls according to the standard assay procedure.

\section{Results and Discussion}

\subsection{Effect of pH on Total POX Activity and Stability}

The total POXs from $A$. viscosus and $A$. israelii were active over $\mathrm{pH}$ range of 4.0 to 9.0 exhibiting above $60 \%$ relative activity over $\mathrm{pH} 6.0$ to 8.5 with optimum $\mathrm{pH}$ at 7.0 (Figure 1 (a)). Some studies have reported optimum $\mathrm{pH}$ for POXs from fungi in the range of 4.0 - 7.0 [20]-[22] while there are reports showing $\mathrm{pH}$ optimum in range of 2.0 - 5.0 for fungal POXs [23]-[25]. In contrast, recently reported bacterial POXs from Pseudomonas sp. SUK1 and Bacillus sp. VUS had optimum pH of 3.0 [26] [27]. Our present studies show that actinobacterial POXs have optimum $\mathrm{pH}$ of 7.0. POXs from both $A$. viscosus and $A$. israelii were very stable between pH 6.0 and 8.0 exhibiting maximum stability at $\mathrm{pH} 7.0$ with $64 \%$ and $77 \%$ relative residual activity at $\mathrm{pH} 6.0$ and 8.0 , respectively (Figure 1(b)). Rodriguez-Couto et al. [28] reported POXs from white rot fungus, Phanerochaete chrysosporium which exhibited great stability only at $\mathrm{pH}$ around 4.5. Also, POX from Pleurotus sajor caju MTCC-141 was stable and active around pH 3.0 [29]. The actinobacterial POXs under study demonstrated unique stability around neutral $\mathrm{pH}$.

\subsection{Effect of Temperature on Total POX Activity and Stability}

The optimum temperature for the activity of total POX from $A$. viscosus was $50^{\circ} \mathrm{C}$. There was a decline in 


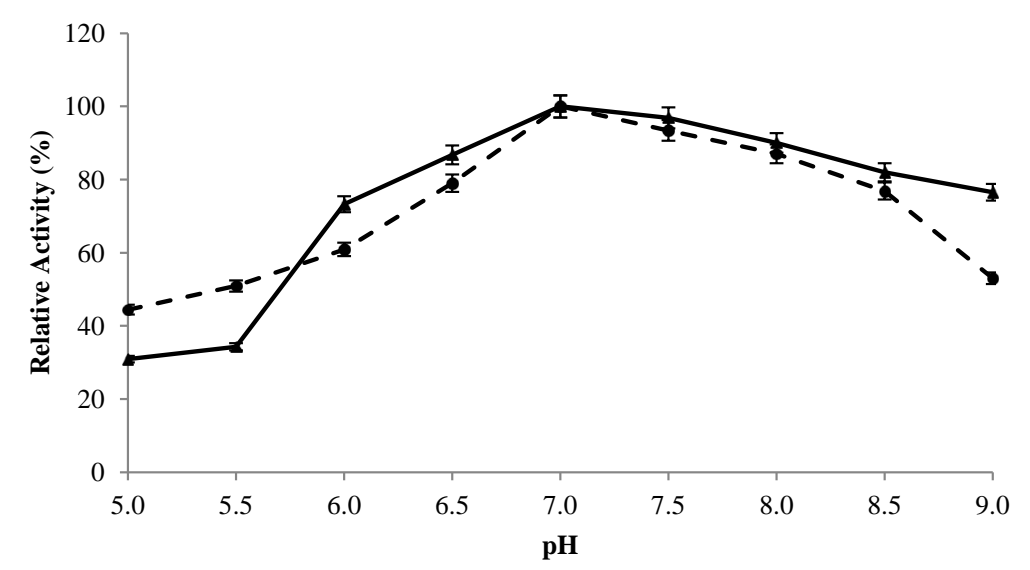

(a)

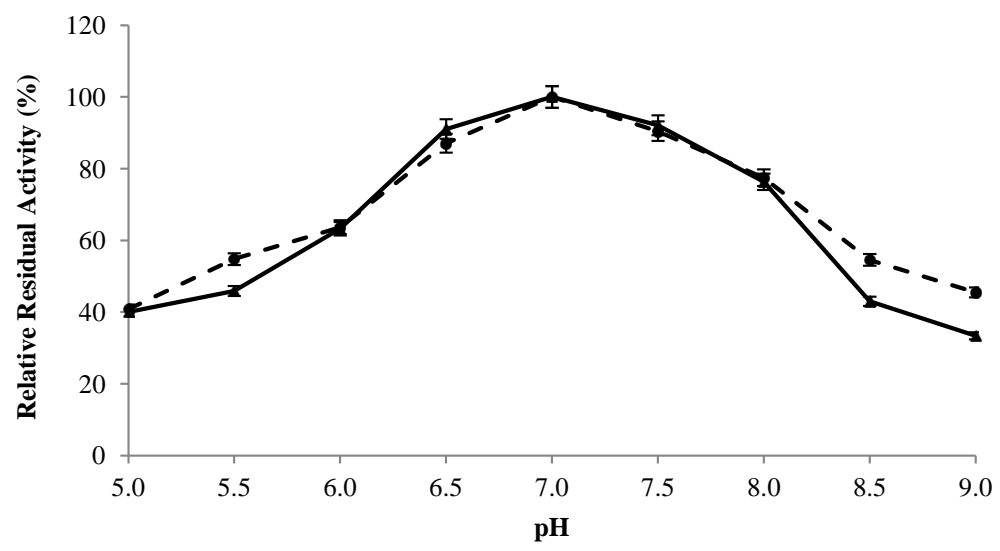

(a)

Figure 1. (a) Effect of pH on activity of POXs from Actinomyces israelii (- - -) and Actinomyces viscosus (-); (b) Effect of $\mathrm{pH}$ on the stability of POXs from A. israelii (- - -) and A. viscosu s (-). Maximum activity was expressed as $100 \%$. Symbols and bars represent mean values and standard deviations of triplicate determinations.

activity at higher temperatures with the enzyme having a relative activity of $65.5 \%$ at $60^{\circ} \mathrm{C}$ (Figure 2(a)). Similar result was obtained for POX from $P$. chrysosporium which was optimally active at $55^{\circ} \mathrm{C}$ [25]. The enzyme showed a drastic loss of activity at $70^{\circ} \mathrm{C}$ exhibiting only $17 \%$ relative activity due to heat denaturation. Total POX from A. israelii had optimum temperature of $40^{\circ} \mathrm{C}$ while it exhibited relative activity of $71 \%$ and $42 \%$ at $50^{\circ} \mathrm{C}$ and $60^{\circ} \mathrm{C}$, respectively. The enzyme also had a drastic loss of activity at $70^{\circ} \mathrm{C}$ similar to what was observed on POX from A. viscosus showing about $17 \%$ relative activity. Similar finding was reported on the bacterial POX from Pseudomonas sp. SUK1 which was optimally active at $40^{\circ} \mathrm{C}$ [26]. Lower optimum temperatures of $25^{\circ} \mathrm{C}$ and $35^{\circ} \mathrm{C}$ have been reported for POXs from B. pumilus and Paenibacillus sp. [22] while POX from Loweporus lividus MTCC-1178 was optimally active at $24^{\circ} \mathrm{C}$ [29]. The difference in optimum temperature of the POXs under study could be related to some structural differences in the total peroxidases. Total POXs from $A$. viscosus and A. israelii showed high stability between $40^{\circ} \mathrm{C}$ and $50^{\circ} \mathrm{C}$ which decreased with time (Figure 2(b)). The enzymes exhibited about $60 \%$ residual relative activity after 60 min incubation at $40^{\circ} \mathrm{C}$ and $45 \%$ relative residual activity at $50^{\circ} \mathrm{C}$ after 60 min incubation, respectively. Activity of total POXs from both species was completely lost at $70^{\circ} \mathrm{C}$ after 150 minutes of incubation. Similarly, POXs from Rhizoctonia sp. SYBC-M3 and $P$. chrysosporium were totally inactivated at $65^{\circ} \mathrm{C}$ [30] [31]. In another report, POX from the white-rot fungus, Irpex lacteus showed high stability between $30^{\circ} \mathrm{C}$ and $40^{\circ} \mathrm{C}$ [32]. Rodríguez-Couto et al. [28] reported POXs from $P$. chrysosporium which were most stable between $32^{\circ} \mathrm{C}$ and $34^{\circ} \mathrm{C}$. High thermostability is an attractive and desirable characteristic of an enzyme for a variety of industrial and biotechnological applications [33]-[35]. The total POXs under study demonstrated higher thermostability than most of the earlier reported POXs. This suggests that the two actinobacteria under study have potential for use in bioremediation and industry as producers of thermostable POXs. 


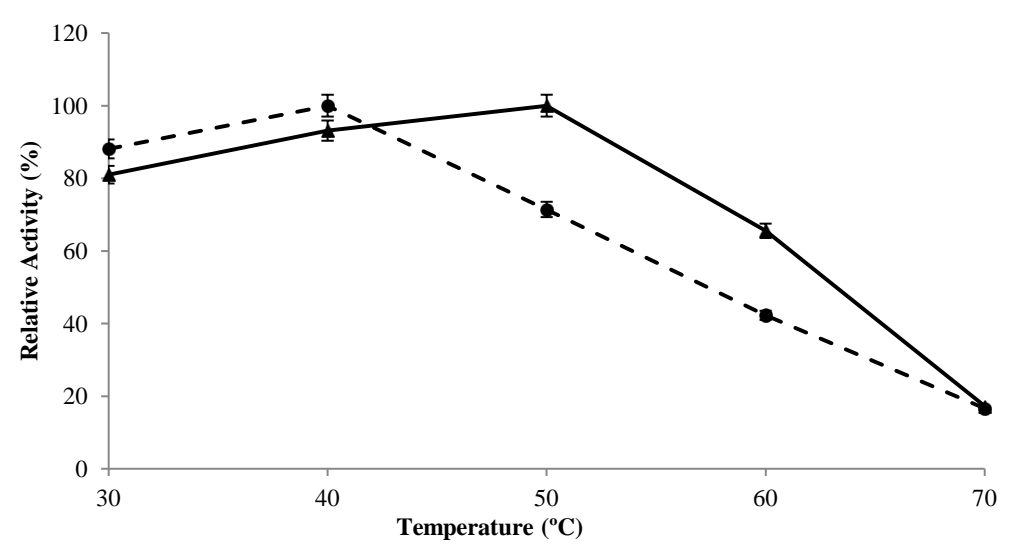

(a)

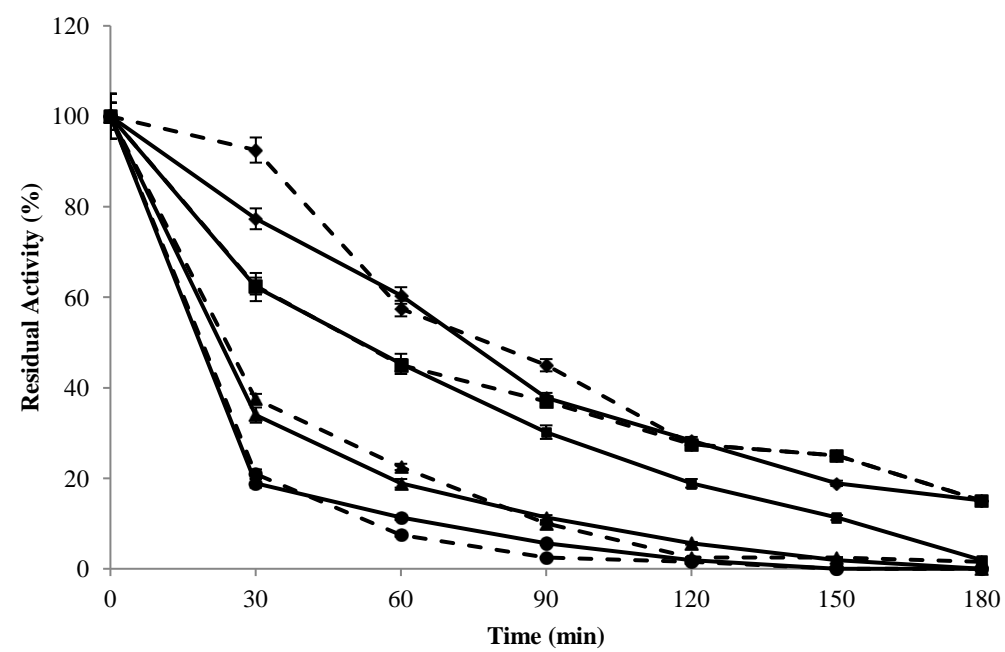

(b)

Figure 2. (a) Effect of temperature on activity of POXs from A. viscosus (-) and A. israelii (---); (b) Effect of varied temperature $\left(40^{\circ} \mathrm{C}(\bullet), 50^{\circ} \mathrm{C}(\boldsymbol{\bullet}), 60^{\circ} \mathrm{C}(\boldsymbol{\Delta})\right.$ and $70^{\circ} \mathrm{C}(\bullet)$ on stability of POXs from A. viscosus and A. israelii over 30 to $180 \mathrm{~min}$ pre-incubation period at Maximum activity was expressed as $100 \%$. Symbols and bars represent mean values and standard deviations of triplicate determinations.

\subsection{Effect of EDTA and Metal Ions on Activity of Total POXs}

EDTA inhibited the activity of the total POXs at $5 \mathrm{mM}$ and completely inhibited the enzyme activity at $10 \mathrm{mM}$. Strong inhibition of POXs by EDTA had been reported in previous studies [36]-[38]. This inhibition is due to metal chelating characteristic of EDTA which makes metal ions that are co-factors for the activity of POXs unavailable to the enzymes. The activity of total POXs from both species under study was enhanced greatly in the presence of 5 and $10 \mathrm{mM} \mathrm{Fe}^{2+}$ (Table 1). The POXs from A. viscosus and A. israelii were activated 22-fold in the presence of $10 \mathrm{mM} \mathrm{Fe}^{2+}$ while activation in the presence of $5 \mathrm{mM} \mathrm{Fe}^{2+}$ was 7- and 8.6-fold for POXs from A. viscosus and A. israelii, respectively. Asgher et al. [36] and Cheng et al. [38] had reported activation of POXs by low concentration of $\mathrm{Fe}^{2+}$ while strong inhibitory effects of $\mathrm{Fe}^{2+}$ on POXs have also been reported in the presence of 1 and $10 \mathrm{mM} \mathrm{Fe}^{2+}$ [38] [39]. Our results have demonstrated that $\mathrm{Fe}^{2+}$ is a possible cofactor for the POXs under study and suggested that the binding of $\mathrm{Fe}^{2+}$ stabilizes and activates the enzymes. However, total POXs from A. viscosus and A. israelii were both strongly inhibited by $\mathrm{Cu}^{2+}, \mathrm{Mg}^{2+}$ and $\mathrm{Hg}^{2+}$ (Table 1). Similar inhibition of activity was reported for POXs in the presence of $\mathrm{Cu}^{2+}, \mathrm{Mg}^{2+}$ and $\mathrm{Hg}^{2+}$ in the studies by Cai et al. [30] and Praveen et al. [37]. The inhibitory characteristic of $\mathrm{Hg}^{2+}$ on most enzymes is due to its high affinity for thiol groups in proteins which leads to inactivation of the enzymes [40]. It is interesting to note that despite the fact that total POXs from A. viscosus and A. israelii exhibit many similar physicochemical properties as congeneric enzymes, they also demonstrated striking differences in their response to $\mathrm{Ca}^{2+}$ and $\mathrm{Mn}^{2+}$. The activity of 
Table 1. Effects of divalent metal ions and EDTA on peroxidase activity.

\begin{tabular}{cccc}
\hline \multirow{2}{*}{ Metal ions } & Concentration $(\mathrm{mM})$ & \multicolumn{2}{c}{ * Relative activity (\%) } \\
\cline { 3 - 4 } & 5 & Actinomyces viscosus & Actinomyces israelii \\
\hline $\mathbf{C a}^{2+}$ & 10 & $136.36 \pm 0.08$ & $62.50 \pm 0.53$ \\
& 5 & $151.82 \pm 0.03$ & $12.50 \pm 0.02$ \\
$\mathbf{F e}^{2+}$ & 10 & $697.27 \pm 0.04$ & $858.75 \pm 0.02$ \\
& 5 & $2236.36 \pm 0.04$ & $2158.75 \pm 0.03$ \\
$\mathbf{C u}^{2+}$ & 10 & $50.91 \pm 0.02$ & $57.50 \pm 0.02$ \\
& 5 & $18.18 \pm 0.02$ & $25.00 \pm 0.03$ \\
$\mathbf{M g}^{2+}$ & 10 & $27.27 \pm 0.01$ & $8.13 \pm 0.01$ \\
& 5 & $13.64 \pm 0.02$ & $6.25 \pm 0.03$ \\
$\mathbf{M n}^{2+}$ & 10 & $106.36 \pm 0.01$ & $62.50 \pm 0.01$ \\
& 5 & $124.54 \pm 0.02$ & $50.47 \pm 0.02$ \\
$\mathbf{H g}^{2+}$ & 10 & $9.09 \pm 0.01$ & $12.50 \pm 0.02$ \\
& 5 & $5.45 \pm 0.02$ & $1.25 \pm 0.03$ \\
EDTA & 10 & $7.04 \pm 0.02$ & $12.50 \pm 0.01$ \\
\end{tabular}

*Relative activity of peroxidase (POX) at each concentration of metal ion was expressed as \% in comparison to the activity of POX of control without metal ion. Data in the table are mean values of triplicate determinations.

total POX from A. viscosus was enhanced by $\mathrm{Ca}^{2+} 1.4-$ and 1.5 -fold at 5 and $10 \mathrm{mM}$ (Table 1). Surprisingly, total POX from A. israelii was inhibited by $\mathrm{Ca}^{2+}$ exhibiting $62.5 \%$ and $12.5 \%$ relative activity in the presence of 5 and $10 \mathrm{mM} \mathrm{Ca}^{2+}$, respectively. Inhibitory effect of $\mathrm{Ca}^{2+}$ on POX activity is quite rare though it was reported by Cheng et al. [38] on POX from white-rot fungus, Schizophyllum sp. F17 which exhibited 89\% relative activity in the presence of $1 \mathrm{mM} \mathrm{Ca}^{2+}$. In another study, $\mathrm{Ca}^{2+}$ had insignificant effect on POX activity [41]. Similar to our results on activation of total POX from A. viscosus by $\mathrm{Ca}^{2+}$ is the report by Praveen et al. [37] on POX from Stereum ostrea. The activation of POXs has been attributed to the role played by the calcium binding sites on proximal and distal domains of the POX structure [42]. $\mathrm{Ca}^{2+}$ has earlier been reported to contribute to structural stability of heme POXs [43]. Peroxidases undergo a catalytic cycle during which electron transfer results in the reduction of $\mathrm{H}_{2} \mathrm{O}_{2}$ to water [17]. The inhibition of total POX from A. israelii by $\mathrm{Ca}^{2+}$ was found to be concentration dependent because the relative activity of the enzyme was lower in the presence of $10 \mathrm{mM} \mathrm{Ca}^{2+}$ than with 5 mM. In fact, activation of POX from S. ostrea reported by Praveen et al. [37] was higher at lower concentration of $\mathrm{Ca}^{2+}(133 \%$ at $1 \mathrm{mM})$ than with higher concentration of $\mathrm{Ca}^{2+}(111 \%$ at $10 \mathrm{mM})$. The disparity in response of the total POXs under study to $\mathrm{Ca}^{2+}$ remains unclear. Interestingly, $\mathrm{Mn}^{2+}$ also enhanced activity of POX from $\mathrm{A}$. viscosus but inhibited the activity of POX from A. israelii at 5 and $10 \mathrm{mM}$ (Table 1). The activity of total POX from A. viscosus was enhanced 1.2-fold in the presence of $10 \mathrm{mM} \mathrm{Mn}^{2+}$ while total POX from A. israelii was strongly inhibited at same concentration exhibiting 50\% relative activity. Janusz et al. [44] reported in a review that $\mathrm{Mn}^{2+}$ enhances manganese peroxidase activity and inhibits lignin peroxidase activity. Cheng et al. [38] in their studies recorded inhibition of POX from Schizophyllum sp. F17 at 0.1 and $1 \mathrm{mM} \mathrm{Mn}^{2+}$ and activation at 10 $\mathrm{mM}$. Activity of POX from A. israelii was inhibited at both 5 and $10 \mathrm{mM} \mathrm{Mn}^{2+}$. The differences in total POXs from these two related species under study suggest that the properties of total POXs produced from $A$. viscosus and A. israelii could be related to the dominant POX in the crude total POX. This further explains that the mechanism of oxidation by the total POXs is not the same in the presence of metal ions.

\section{Conclusion}

Effects of metal ions on the POXs suggest that the presence of metal ions in oil contaminated sites could either promote or hinder bioremediation process. The total POXs under study from the same genus, Actinomyces, but different species, were found to possess very similar properties. However, there was a very clear distinction between the total POXs in their tolerance to $\mathrm{Ca}^{2+}$ and $\mathrm{Mn}^{2+}$. The differing characteristics could be related to difference in flexibility of the active sites of individual POXs constituting the total POX. Detailed purification and characterization of these congeneric POXs are in progress to provide further insights into their mechanism of action. The physicochemical properties of total extracellular POXs from A. viscosus and A. israelii have estab- 
lished the optimum conditions under which the actinobacteria under study could be effective for bioremediation purposes.

\section{Acknowledgements}

Authors thank the technical staff of Biotechnology Unit, Federal Institute of Industrial Research Oshodi, Lagos, Nigeria for their contribution in the identification of actinobacterial isolates.

\section{References}

[1] Nwaichi, E.O., Wegwu, M.O. and Nwosu, U.L. (2014) Distribution of Selected Carcinogenic Hydrocarbon and Heavy Metals in an Oil-Polluted Agriculture Zone. Environmental Monitoring and Assessment, 186, 8697-8706. http://dx.doi.org/10.1007/s10661-014-4037-6

[2] Stark, J.S., Kim, S.L. and Oliver, J.S. (2014) Anthropogenic Disturbance and Biodiversity of Marine Benthic Communities in Antarctica: A Regional Comparison. PLOS ONE, 9, e98802. http://dx.doi.org/10.1371/journal.pone.0098802

[3] Marshall, A.G. and Rodgers, R.P. (2004) Petroleomics: The Next Grand Challenge for Chemical Analysis. Accounts of Chemical Research, 37, 53-59. http://dx.doi.org/10.1021/ar020177t

[4] Van Hamme, J.D., Singh, A. and Ward, O.P. (2003) Recent Advances in Petroleum Microbiology. Microbiology and Molecular Biology Reviews, 67, 503-549. http://dx.doi.org/10.1128/MMBR.67.4.503-549.2003

[5] Samanta, S.K., Singh, O.V. and Jain, R.K. (2002) Polycyclic Aromatic Hydrocarbons: Environmental Pollution and Bioremediation. Trends in Biotechnology, 20, 243-248. http://dx.doi.org/10.1016/S0167-7799(02)01943-1

[6] Coulon, F., McKew, B.A., Osborn, A.M., McGenity, T.J. and Timmis, K.N. (2006) Effects of Temperature and Biostimulation on Oil-Degrading Microbial Communities in Temperate Estuarine Waters. Environmental Microbiology, 9, 177-186. http://dx.doi.org/10.1111/j.1462-2920.2006.01126.x

[7] Sathishkumar, M., Binupriya, A.R., Baik, S.-H. and Yun, S.-E. (2008) Biodegradation of Crude Oil by Individual Bacterial Strains and a Mixed Bacterial Consortium Isolated from Hydrocarbon Contaminated Areas. CLEAN-Soil, Air, Water, 35, 92-96. http://dx.doi.org/10.1002/clen.200700042

[8] Baek, K.H., Yoon, B.D., Kim, B.H., et al. (2007) Monitoring of Microbial Diversity and Activity during Bioremediation of Crude Oil-Contaminated Soil with Different Treatments. Journal of Microbiology and Biotechnology, 17, 6773.

[9] Kang, Y.S., Park, Y.J., Jung, J. and Park, W. (2009) Inhibitory Effect of Aged Petroleum Hydrocarbons on the Survival of Inoculated Microorganism in a Crude-Oil-Contaminated Site. Journal of Microbiology and Biotechnology, 19, 1672-1678. http://dx.doi.org/10.4014/jmb.0903.03001

[10] Lin, T.C., Pan, P.T. and Cheng, S.S. (2010) Ex Situ Bioremediation of Oil-Contaminated Soil. Journal of Hazardous Materials, 176, 27-34. http://dx.doi.org/10.1016/j.jhazmat.2009.10.080

[11] Acevedo, F., Pizzul, L., Castillo, M.D., Gonzalez, M.E., Cea, M., et al. (2010) Degradation of Polycyclic Aromatic Hydrocarbons by Free and Nanoclay Immobilized Manganese Peroxidase from Anthracophyllum discolor. Chemosphere, 80, 271-278. http://dx.doi.org/10.1016/j.chemosphere.2010.04.022

[12] McGenity, T.J., Folwell, B.D., McKew, B.A. and Sanni, G.O. (2012) Marine Crude-Oil Biodegradation: A Central Role for Interspecies Interactions. Aquatic Biosystems, 8, 10. http://dx.doi.org/10.1186/2046-9063-8-10

[13] Haritash, A.K. and Kaushik, C.P. (2009) Biodegradation Aspects of Polycyclic Aromatic Hydrocarbons (PAHs): A Review. Journal of Hazardous Materials, 169, 1-15. http://dx.doi.org/10.1016/j.jhazmat.2009.03.137

[14] Baborova, P., Moder, M., Baldrian, P., Cajthamlova, K. and Cajthamlova, T. (2006) Purification of a New Manganese Peroxidase of the White-Rot Fungus Irpex lacteus and Degradation of Polycyclic Aromatic Hydrocarbons by the Enzyme. Research in Microbiology, 157, 248-253. http://dx.doi.org/10.1016/j.resmic.2005.09.001

[15] Eibes, G., Cajthaml, T., Moreira, M.T., Feijoo, G. and Lema, J.M. (2006) Enzymatic Degradation of Anthracene, Dibenzothiophene and Pyrene by Manganese Peroxidase in Media Containing Acetone. Chemosphere, 64, 408-414. http://dx.doi.org/10.1016/j.chemosphere.2005.11.075

[16] Niladevi, K.N. and Prema, P. (2005) Mangrove Actinomycetes as the Source of Ligninolytic Enzymes. Actinomycetologica, 19, 40-47. http://dx.doi.org/10.3209/saj.19.40

[17] Le Roes-Hill, M., Khan, N. and Burton, S.G. (2011) Actinobacterial Peroxidases: An Unexplored Resource for Biocatalysis. Applied Biochemistry and Biotechnology, 164, 681-713. http://dx.doi.org/10.1007/s12010-011-9167-5

[18] Whitman, W., Goodfellow, M., Kämpfer, P., Busse, H., Trujillo, M.E., Ludwig, W., Suzuki, K. and Parte, A., Eds. (2012) The Actinobacteria: Bergey’s Manual of Systematic Bacteriology. 2nd Edition, Springer-Verlag, UK. 
[19] Hunter, C.L., Maurus, R., Mauk, M.R., Lee, H., Raven, E.L., Tong, H., Nguyen, N., Smith, M., Brayer, G.D. and Mauk, A.G. (2003) Introduction and Characterization of a Functionally Linked Metal Ion Binding Site at the Exposed Heme Edge of Myoglobin. Proceedings of the National Academy of Sciences of the United States of America, 100, 3647-3652. http://dx.doi.org/10.1073/pnas.0636702100

[20] Hakala, T.K., Lundell, T., Galkin, S., Maijala, P., Kalkkinen, S. and Hatakka, A. (2005) Manganese Peroxidases, Laccase and Oxalic Acid from the Selective White-Rot Fungus Physisporinus rivulosus Grown on Spruce Wood Chips. Enzyme and Microbial Technology, 36, 461-468. http://dx.doi.org/10.1016/j.enzmictec.2004.10.004

[21] Asgher, M., Bhatti, H.N., Ashraf, M. and Legge, R.L. (2008) Recent Developments in Biodegradation of Industrial Pollutants by White Rot Fungi and Their Enzyme System. Biodegradation, 19, 771-783. http://dx.doi.org/10.1007/s10532-008-9185-3

[22] De Oliveira, P.L., Duarte, M.C.T., Ponezi, A.N. and Durrant, L.R. (2009) Purification and Partial Characterization of Manganese Peroxidase from Bacillus pumilus and Paenibacillus sp. Brazilian Journal of Microbiology, 40, 818-826. http://dx.doi.org/10.1590/S1517-83822009000400012

[23] Snajdr, J. and Baldrian, P. (2007) Temperature Effects the Production, the Activity and Stability in Lignolytic Enzymes in Pleurotus ostreatus and Trametes versicolor. Folia Microbiologica, 52, 498-502. http://dx.doi.org/10.1007/BF02932110

[24] Yang, J.S., Yuan, H.L. and Chen, W.X. (2004) Studies on Extracellular Enzymes of Lignin Degrading Fungus Penicillium sp. P6. China Environmental Science, 24, 24-27.

[25] Alam, M.Z., Mansor, M.F. and Jalal, K.C.A. (2009) Optimization of Lignin Peroxidase Production and Stability by Phanerochaete chrysosporium Using Sewage-Treatment-Plant Sludge as Substrate in a Stirred-Tank Bioreactor. Journal of Industrial Microbiology \& Biotechnology, 36, 757-764. http://dx.doi.org/10.1007/s10295-009-0548-5

[26] Kalyani, D.C., Phugare, S.S., Shedbalkar, U.U. and Jadhav, J.P. (2011) Purification and Characterization of a Bacterial Peroxidase from the Isolated Strain Pseudomonas sp. SUK1 and Its Application for Textile Dye Decolorization. Annals of Microbiology, 61, 483-491. http://dx.doi.org/10.1007/s13213-010-0162-9

[27] Dawkar, V.V., Jadhav, U.U., Telke, A.A. and Govindwar, S.P. (2009) Peroxidase from Bacillus sp. VUS and Its Role in the Decolorization of Textile Dyes. Biotechnology and Bioprocess Engineering, 14, 361-368. http://dx.doi.org/10.1007/s12257-008-0242-x

[28] Rodriguez-Couto, S., Moldes, D. and Sanroma, M.A. (2006) Optimum Stability Conditions of pH and Temperature for Ligninase and Manganese-Dependent Peroxidase from Phanerochaete chrysosporium. Application to in Vitro Decolorization of Poly R-478 by MnP. World Journal of Microbiology and Biotechnology, 22, 607-612. http://dx.doi.org/10.1007/s11274-005-9078-0

[29] Yadav, M., Singh, S.K. and Yadav, K.D.S. (2009) Purification and Characterization of Lignin Peroxidase from Pleurotus sajor caju MTCC-141. Journal of Wood Chemistry and Technology, 29, 59-73. http://dx.doi.org/10.1080/02773810802596489

[30] Cai, Y.H., Wu, X., Liao, Y., Sun, D.J. and Zhang, D.B. (2010) Purification and Characterization of Novel Manganese Peroxidase from Rhizoctonia sp. SYBC-M3. Biotechnology and Bioprocess Engineering, 15, 1016-1021. http://dx.doi.org/10.1007/s12257-010-0130-z

[31] Urek, R.O. and Pazarlioglu, N.K. (2004) Purification and Partial Characterization of Manganese Peroxidase from Immobilized Phanerochaete chrysosporium. Process Biochemistry, 39, 2061-2068. http://dx.doi.org/10.1016/j.procbio.2003.10.015

[32] Shin, K.S., Kim, Y.H. and Lim, J.S. (2005) Purification and Characterization of Manganese Peroxidase of the WhiteRot Fungus Irpex lacteus. Journal of Microbiology, 43, 503-509.

[33] Beg, Q.K. and Gupta, R. (2003) Purification and Characterization of an Oxidation Stable, Thiol-Dependent Serine Alkaline Protease from Bacillus mojavensis. Enzyme and Microbial Technology, 32, 294-304. http://dx.doi.org/10.1016/S0141-0229(02)00293-4

[34] Joo, H.-S., Kumar, C.G., Park, G.-C., Paik, S.R. and Chang, C.-S. (2003) Oxidant and SDS-Stable Alkaline Protease from Bacillus clausii I-52: Production and Some Properties. Journal of Applied Microbiology, 95, 267-272. http://dx.doi.org/10.1046/j.1365-2672.2003.01982.x

[35] Haddar, A., Agrebi, R., Bougatef, A., Hmidet, N., Sellami-Kamoun, A. and Nasri, M. (2009) Two Detergent Stable Alkaline Serine-Proteases from Bacillus mojavensis A21: Purification, Characterization and Potential Application as a Laundry Detergent Additive. Bioresource Technology, 100, 3366-3373. http://dx.doi.org/10.1016/j.biortech.2009.01.061

[36] Asgher, M., Iqbal, H.M.N. and Irshad, M. (2012) Characterization of Purified and Xerogel Immobilized Novel Lignin Peroxidase Produced from Trametes versicolor IBL-04 Using Solid State Medium of Corncobs. BMC Biotechnology, 12, 46. http://dx.doi.org/10.1186/1472-6750-12-46 
[37] Praveen, K., Usha, K.Y., Viswanath, B. and Rajasekhar Reddy, B. (2012) Kinetic Properties of Manganese Peroxidase from the Mushroom Stereum ostrea and Its Ability to Decolorize Dyes. Journal of Microbiology and Biotechnology, 22, 1540-1548. http://dx.doi.org/10.4014/jmb.1112.12011

[38] Cheng, X., Jia, R., Li, P., Tu, S., Zhu, Q., et al. (2007) Purification of a New Manganese Peroxidase of the White-Rot Fungus Schizophyllum sp. F17 and Decolorization of Azo Dyes by the Enzyme. Enzyme and Microbial Technology, 1, 258-264.

[39] Asgher, M. and Iqbal, H.M.N. (2011) Characterization of a Novel Manganese Peroxidase Purified from Solid State Culture of Trametes versicolor IBL-04. BioResources, 6, 4302-4315.

[40] Baldrian, P., Wiesche, C., Gabriel, J., Nerud, F. and Zadrazil, F. (2000) Influence of Cadmium and Mercury on Activities of Ligninolytic Enzymes and Degradation of Polycyclic Aromatic Hydrocarbons by Pleurotus ostreatus in Soil. Applied and Environmental Microbiology, 66, 2471-2478. http://dx.doi.org/10.1128/AEM.66.6.2471-2478.2000

[41] Boer, C.G.L., Obici, C.G., de Souza, M. and Peralta, R.M. (2006) Purification and Some Properties of Mn Peroxidase from Lentinula edodes. Process Biochemistry, 41, 1203-1207. http://dx.doi.org/10.1016/j.procbio.2005.11.025

[42] Banci, L., Camarero, S., Martínez, A.T., Martínez, M.J., Pérez-Boada, M., Pierattelli, R., et al. (2003) NMR Study of Mn(II) Binding by the New Versatile Peroxidase from the White-Rot Fungus Pleurotus eryngii. Journal of Biological Inorganic Chemistry, 8, 751-760. http://dx.doi.org/10.1007/s00775-003-0476-1

[43] Sutherland, G.R., Zapanta, L.S., Tien, M. and Aust, S.D. (1997) Role of Calcium in Maintaining the Heme Environment of Manganese Peroxidase. Biochemistry, 36, 3654-3662. http://dx.doi.org/10.1021/bi962195m

[44] Janusz, G., Kucharzyk, K.H., Pawlika, A., Staszczaka, M. and Paszczynski, A.J. (2013) Fungal Laccase, Manganese Peroxidase and Lignin Peroxidase: Gene Expression and Regulation. Enzyme and Microbial Technology, 52, 1-12. http://dx.doi.org/10.1016/j.enzmictec.2012.10.003 